\title{
ブナハリタケ培養菌糸体に含まれるフェニルペンタノン誘導体とそれら化合物の合成
}

\author{
佐藤寛次, ${ }^{*}$ 山城 崇, 野村正幸, 中田真一
}

\section{The Derivatives of Phenylpentanone in Cultured Mycelium of Mycoleptodonoides aitchisonii and the Syntheses of Their Compounds}

\author{
Kanji SATOH, ${ }^{*}$ Takashi YAmashiro, Masayuki Nomura, and Shinichi NaKATA \\ Department of Applied Chemistry for Environments, Faculty of Engineering and Resource Science, \\ Akita University, 1-1 Tegatagakuen-machi, Akita City 010-8502, Japan
}

(Received April 5, 2008; Accepted August 29, 2008)

\begin{abstract}
A new perfumed dihydro- $\gamma$-pyrone, 2-phenyl-5,6-dihydro- $4 H$-pyrane-4-one (12) and seven components of C6-C5 phenylpentanone derivatives have been isolated from the neutral essential oil parts in cultured mycelium of Mycoleptodonoides aitchisonii. These compounds were elucidated on the basis of spectral data and syntheses. The derivatives are odorant components. The perfumed components in cultured mycelium were maximized amount at 7 days.
\end{abstract}

Key words — Mycoleptodonoides aitchisonii; phenylpentanone derivatives; odorant compound; cultured mycelium

\section{緒 \\ 論 \\ ブナハリタケ (Mycoleptodonoides aitchisonii)} は独特のアニス様芳香を有する食用菌（東北地方 名：カヌカ） で，1-フェニル-3-ペンタノン $(\mathbf{5})$ 及び 1-フェニル-3-ペンタノール $(6)$ の芳香成分が知られ ている。最近，これら香気成分 $(\mathbf{5}, \mathbf{6})$ の投与で，ラ ット線条体切片からドーパミンの放出促進作用が確 認されている. ${ }^{1,2)}$ 医薬資源としての可能性があるこ れら化合物の生理活性評価には，天然物からの分離 品に加えて，合成品の利用が有効である，本報で は，ブナハリタケ菌糸体の培養により生産される芳 香成分を単離し，構造を決定した。ささに，これら フェニルペンタノン誘導体を合成した。 また天然ブ ナハリタケにはみられない新規ジヒドロ- $\gamma$-ピロン 化合物 (12) を合成した。 ${ }^{3,4)}$

\section{実 験 の 部}

\section{1. 一般分析 融点は, ヤナコ微量融点測定器} （MP-500D）で測定，未補正である，FT-IR スペク トルは，JASCO FT-IR 5300 を用い，臭化カリウム 錠剂法で行った。 ${ }^{1} \mathrm{H}$ 及び ${ }^{13} \mathrm{C}-\mathrm{NMR}$ スペクトル

秋田大学工学資源学部環境応用化学科

*e-mail: kanji123@ipc.akita-u.ac.jp
は，内部基準にテトラメチルシランを含む $\mathrm{CDCl}_{3}$ 溶液中, JEOL JNM-GX 270, 及び JEOL JNMGX 400 FT-NMR 装置により観測した。化学シフト 值は $\delta$ 值（ppm）で表した。 MS スペクトルは， JEOL JMS-DX 300 GC/MS 装置を用い，EI 法（イ オン化電圧 $70 \mathrm{eV}$ ）で測定した。 GC-MS スペクト ルは, 日本電子 DX-300 装置を用いて分析した。 GC 分析は，島津 GC-8A/C-R3A 装置を用い，シリ コン充填凨 SE-30（30\% Chromosob W）を充填し た $3 \mathrm{~m}$ のガラスカラムを用いて行った。 カラム温 度は $210^{\circ} \mathrm{C}$, 注入部温度は $310^{\circ} \mathrm{C}$, 検出器は水素炎 イオン化検出器を用いた。 HPLC は, UV 検出器 （254 nm）が付属した Waters 600 Multisolvent Delivery System 装置を用いた．CD は，日本分光 DIP 1000 装置を用いた。

2. 試薬液体ホルムアルデヒドは, パラホル ムアルデヒドの熱分解により発生するホルムアルデ ヒドを，ドライアイスーメタノール寒剤で冷却した $n$-ヘキサンのトラップに捕集，液化させて用い た。 その他試薬は, 市販特級品をそのまま用いた.

3. 菌糸培養と精油成分の抽出 植菌する $M$. aitchisonii 菌糸体は，ブナハリタケ子実体（秋田県 大仙市田沢湖で採集）の組織培養で得た。組織培養 は $500 \mathrm{ml}$ の三角フラスコに $300 \mathrm{ml}$ の培養液を調製 
し行った．グルコース $(20 \mathrm{~g} / 1)$ ，ポリペプトン（5 $\mathrm{g} / \mathrm{l})$ ，酵母エキス（2g/l），消泡剂（1 g/l）及び水 （11）を加えた組成液を $120^{\circ} \mathrm{C} ， 35$ 分間殺菌処理, 冷却後植菌した。脱脂綿で栓をし，振とう器で穏や かに振り混ぜ，3 日間培養し菌糸体を得た。次に， 901 の発酵槽に上記と同様な組成液 501 を入れ, $120^{\circ} \mathrm{C}, 35$ 分間殺菌処理, 冷却後, 先に培養した菌 糸体と培養液 $300 \mathrm{ml}$ を移植した。最初に $25^{\circ} \mathrm{C}$, 回 転数 $100 \mathrm{rpm}$ で 10 日間培養した。2 回目からは, 芳香精油成分が最大值になる 7 日まで，3 回培養製 造した。各液を合算，乃過，ろ液 20031 と菌糸体 $1015 \mathrm{~g}$ を得た。ろ液をエーテル抽出（2 回），飽和 炭酸水素ナトリウム水溶液で処理，常法により，中 性精油 $179 \mathrm{~g}$ (収率 $9.0 \%$ ), 酸性精油 $4.05 \mathrm{~g}$ （収率 0.2\%）をそれぞれ得た。

4. 中性精油成分の分離 ·同定中性精油 $(95.3 \mathrm{~g})$ を減圧蒸留により, Fr.1: bp. $70-79^{\circ} \mathrm{C} / 5$ torr, $8.2 \mathrm{~g}$, Fr.2: bp $.82-86^{\circ} \mathrm{C} / 5$ torr, $11.4 \mathrm{~g}$, Fr. 3 : bp. $99-102^{\circ} \mathrm{C} / 5$ torr, $17.5 \mathrm{~g}$, Fr. 4 : bp. $110-131^{\circ} \mathrm{C} / 5$ torr, $21.6 \mathrm{~g}$, 及び Fr.5: bp. $135-176^{\circ} \mathrm{C} / 5$ torr, $14.4 \mathrm{~g}$ に分留した．各留分の成分比（\%）は，Fr.1：1：9， 2: 18, 3: 31, 4: 25, 5: 8\%, Fr.2: 4: 11, 5: 47, 6: 34\%, Fr.3: 5: 21, 6: 44, 7: 16, 8: 15\%, Fr.4: 6: 12, 7: 5, 8: 28, 9: 6, 10: 11, 11: 14, 12: 18\%, Fr.5: 7: 4, 8: 24, 9: 7, 10: 9, 11: 9, 12: 41\%であった

蒸留残部 $10.2 \mathrm{~g}$ を, ベンゼンを用いたシリカゲ ルカラムクロマトグラフィー（内径 $40 \mathrm{~mm} \times 300$ mm, $150 \mathrm{~g}$ ) で, Fr.1-Fr.40に分画した。Fr.36Fr.40 分画をシクロヘキサンから再結晶し， 10 を得 た. Fr.30-Fr.33 分画を, HPLC (5-ODS-H カラム, $n$-ヘキサン：ジクロロメタン $=4: 1)$ で精製し, 12 を得た。

5 : 無色油状物, IR $(\mathrm{KBr}) \mathrm{cm}^{-1}: 1720(v-\mathrm{C}=\mathrm{O})$, $1618(v-\mathrm{C}=\mathrm{C}),{ }^{1} \mathrm{H}-\mathrm{NMR}\left(\mathrm{CDCl}_{3}\right) \delta: 1.01(3 \mathrm{H}, \mathrm{t}, J$ $=6.0 \mathrm{~Hz}, \mathrm{H}-5), 2.35(2 \mathrm{H}, \mathrm{q}, J=6.0 \mathrm{~Hz}, \mathrm{H}-4), .2 .60-$ $2.98(4 \mathrm{H}, \mathrm{m}, \mathrm{H}-1, \mathrm{H}-2), 7.20(5 \mathrm{H}, \mathrm{s})$.

6: 無色油状物, IR (KBr) $\mathrm{cm}^{-1}: 3600-3100(v-$ $\mathrm{O}-\mathrm{H}),{ }^{1} \mathrm{H}-\mathrm{NMR}\left(\mathrm{CDCl}_{3}\right) \delta: 0.92(3 \mathrm{H}, \mathrm{t}, J=6.0 \mathrm{~Hz}$, $\mathrm{H}-5), 1.16-1.88$ (4H, m, H-2, H-4) , 2.56-2.85 (2H, $\mathrm{m}, \mathrm{H}-1), 3.52(1 \mathrm{H}, \mathrm{tt}, J=6.0 \mathrm{~Hz}, \mathrm{H}-3)$.

7 : 無色プリズム状結晶, $\mathrm{mp} .38-39^{\circ} \mathrm{C}(n-$ ヘキサ ン), IR $(\mathrm{KBr}) \mathrm{cm}^{-1}: 1680(v-\mathrm{C}=\mathrm{O}), 1648,1620(v-$ $\mathrm{C}=\mathrm{C}),{ }^{1} \mathrm{H}-\mathrm{NMR}\left(\mathrm{CDCl}_{3}\right) \delta: 1.14(3 \mathrm{H}, \mathrm{t}, J=6.0 \mathrm{~Hz}$,
$\mathrm{H}-5), 2.61(2 \mathrm{H}, \mathrm{q}, J=6.0 \mathrm{~Hz}, \mathrm{H}-4), 6.55(1 \mathrm{H}, \mathrm{d}, J$ $=16.0 \mathrm{~Hz}, \mathrm{H}-2), 7.30(5 \mathrm{H}, \mathrm{s}), 7.48(1 \mathrm{H}, \mathrm{d}, J=16.0$ $\mathrm{Hz}, \mathrm{H}-1)$.

8 : 淡黄色油状物, IR $(\mathrm{KBr}) \mathrm{cm}^{-1}: 3460(v-\mathrm{O}-\mathrm{H})$, $1720(v-\mathrm{C}=\mathrm{O}) ;{ }^{1} \mathrm{H}-\mathrm{NMR}\left(\mathrm{CDCl}_{3}\right) \delta: 1.05(3 \mathrm{H}, \mathrm{t}, J$ $=7.0 \mathrm{~Hz}, \mathrm{H}-5), 2.45(2 \mathrm{H}, \mathrm{q}, J=7.0 \mathrm{~Hz}, \mathrm{H}-4), 2.90$ $(1 \mathrm{H}, \mathrm{d}, J=9.0 \mathrm{~Hz}, \mathrm{H}-2), 3.02(1 \mathrm{H}, \mathrm{d}, J=5.0 \mathrm{~Hz}$, $\mathrm{H}-2), 3.10(1 \mathrm{H}, \mathrm{brd}, \mathrm{C}-1,-\mathrm{OH}) .4 .35(1 \mathrm{H}, \mathrm{dd}, J=$ $9.0 \mathrm{~Hz}, J=5.0 \mathrm{~Hz}), 7.26((5 \mathrm{H}, \mathrm{s}), \mathrm{MS} m / z: 178$ $\left(\mathrm{M}^{+}\right), 145\left(\mathrm{M}^{+}-\mathrm{C}_{2} \mathrm{H}_{3}\right), 107\left(\mathrm{M}^{+}-\mathrm{C}_{4} \mathrm{H}_{7} \mathrm{O}\right)$.

9: 無色油状物, IR $(\mathrm{KBr}) \mathrm{cm}^{-1}: 3457$ ( $\left.v-\mathrm{O}-\mathrm{H}\right)$, $1715,1677,1642(v-\mathrm{C}=\mathrm{O}), 1634,1521(v-\mathrm{C}=\mathrm{C})$, ${ }^{1} \mathrm{H}-\mathrm{NMR}\left(\mathrm{CDCl}_{3}\right) \delta: 5.65(1 \mathrm{H}, \mathrm{dd}, J=3.75 \mathrm{~Hz}, J=$ $3.75 \mathrm{~Hz} \mathrm{H}-4), 6.22(1 \mathrm{H}, \mathrm{s}, \mathrm{H}-2), 6.27(2 \mathrm{H}, \mathrm{d}, J=$ $3.75 \mathrm{~Hz}, \mathrm{H}-5), 7.30-7.60(3 \mathrm{H}, \mathrm{m}$, ベンゼン $o, p$ 置換)，7.72-8.02 (2H, m, ベンゼン $m$ - 置換), $15.62(1 \mathrm{H}$, brd, $\mathrm{C}-1,-\mathrm{OH}), \mathrm{MS} \mathrm{m} / \mathrm{z}: 174\left(\mathrm{M}^{+}\right), 147$ $\left(\mathrm{M}^{+}-\mathrm{C}_{2} \mathrm{H}_{3}\right), 105\left(\mathrm{M}^{+}-\mathrm{C}_{4} \mathrm{H}_{5} \mathrm{O}\right)$.

10 : 無色針状結晶, $\mathrm{mp} .64-65.5^{\circ} \mathrm{C}$ (シクロへキ サン $),[\alpha]_{\mathrm{D}}^{23}-16.9 \quad(\mathrm{c}=1.0, \quad \mathrm{EtOH}), \quad$ IR $\quad(\mathrm{KBr})$ $\mathrm{cm}^{-1}: 3460(v-\mathrm{O}-\mathrm{H}),{ }^{\mathrm{T}} \mathrm{H}-\mathrm{NMR}\left(\mathrm{CDCl}_{3}\right) \delta: 0.94(3 \mathrm{H}$, $\mathrm{t}, J=7.58 \mathrm{~Hz}, \mathrm{H}-5), 1.55(2 \mathrm{H}, \mathrm{qd}, J=7.58 . J=6.26$ $\mathrm{Hz}, \mathrm{H}-4), 1.81(2 \mathrm{H}, \mathrm{m}, \mathrm{H}-2), 2.80(1 \mathrm{H}, \mathrm{s}, \mathrm{C}-3$, $-\mathrm{OH}), 3.17(1 \mathrm{H}, \mathrm{s}, \mathrm{C}-1,-\mathrm{OH}), 3.89(1 \mathrm{H}, \mathrm{tt}, J=6.26$ $\mathrm{Hz}, J=5.94 \mathrm{~Hz}, \mathrm{H}-3), 4.95(1 \mathrm{H}, \mathrm{dd}, J=4.97 \mathrm{~Hz} . J=$ $2.43 \mathrm{~Hz}, \mathrm{H}-1),{ }^{13} \mathrm{C}-\mathrm{NMR}\left(\mathrm{CDCl}_{3}\right) \delta: 9.57(\mathrm{C}-5)$, 30.95 (C-4), 45.03 (C-2), 74.14 (C-3), 75.49 (C-1), $125.70 （ C \times 2$ ， ベンゼン骨格炭素 2, 6 位 $) ， 127.66$ (ベンゼン骨格炭素 4 位)，128.56（C×2，ベンゼ ン骨格炭素 3, 5 位)，144.57（ベンゼン骨格炭素 1 位). Anal. Calcd for $\mathrm{C}_{11} \mathrm{H}_{16} \mathrm{O}_{2}$. C: 73.30, H: 8.95, O: 17.75 . Found. C: $73.25, \mathrm{H}: 8.82$, O: 17.93 .

11 ：無色針状結晶, mp.66-67.5 ${ }^{\circ} \mathrm{C}$ （シクロヘキ サン), $[\alpha]_{\mathrm{D}}^{24}-27.9 \quad(\mathrm{c}=1.0, \quad \mathrm{EtOH}), \quad$ IR $\quad(\mathrm{KBr})$ $\mathrm{cm}^{-1}: 3460(v-\mathrm{O}-\mathrm{H}) ;{ }^{1} \mathrm{H}-\mathrm{NMR}\left(\mathrm{CDCl}_{3}\right) \delta: 0.97(3 \mathrm{H}$, $\mathrm{t}, J=7.6 \mathrm{~Hz}, \mathrm{H}-5), 1.46(2 \mathrm{H}, \mathrm{m}, \mathrm{H}-4), 2.35-2.98$ $(2 \mathrm{H}$, brds, H-2) $3.88(1 \mathrm{H}, \mathrm{dd}, J=6.5 \mathrm{~Hz}, J=6.0$ $\mathrm{Hz}, \mathrm{H}-3), 5.02(1 \mathrm{H}, \mathrm{dd}, J=5.7 \mathrm{~Hz}, J=2.6 \mathrm{~Hz}, \mathrm{H}-1)$. Anal. Calcd for $\mathrm{C}_{11} \mathrm{H}_{16} \mathrm{O}_{2}: \mathrm{C}: 73.30, \mathrm{H}:$ 8.95, O: 17.75. Found. C: $73.28, \mathrm{H}: 8.83$, O: 17.8 .

12 ：無色鱗片状結晶, $\mathrm{mp} .68-69^{\circ} \mathrm{C}$ （シクロへキ サン), IR $(\mathrm{KBr}) \mathrm{cm}^{-1}: 1650(v-\mathrm{C}=\mathrm{O}), 1600(v-\mathrm{C}$ $=\mathrm{C}), 774,687$ (モノ置換ベンゼン), ${ }^{1} \mathrm{H}-\mathrm{NMR}$ 
$\left(\mathrm{CDCl}_{3}\right) \delta: 2.65(2 \mathrm{H}, \mathrm{t}, J=6.75 \mathrm{~Hz}, \mathrm{H}-5), 4.66(2 \mathrm{H}$, t, $J=6.75 \mathrm{~Hz}, \mathrm{H}-6), 6.02$ (1H, s. H-3), 7.39-7.75 $(5 \mathrm{H}, \mathrm{m}),{ }^{13} \mathrm{C}-\mathrm{NMR}\left(\mathrm{CDCl}_{3}\right) \delta: 36.01(\mathrm{C}-5), 68.23$ (C-6)，102.41（C-3)，126.47（C×2，ベンゼン骨格 炭素 3, 5 位)，128.65（C×3，ベンゼン骨格炭素 2, 4, 6 位)，131.63（C-2），132.65（ベンゼン骨格炭 素 1 位), 70.39 (C-3), MS $m / z: 174\left(\mathrm{M}^{+}\right), 146$ $\left(\mathrm{M}^{+}-\mathrm{C}_{4} \mathrm{H}_{5} \mathrm{O}\right), 105,77$. Anal. Calcd for $\mathrm{C}_{11} \mathrm{H}_{10} \mathrm{O}_{2}$. C: 75.84, H: 5.79, O: 18.37. Found. C: 75.97, H: 5.89, O: 18.14

\section{5, 6, 7, 8, 11 及び 12 の合成}

7 : ベンズアルデヒド $(12.7 \mathrm{~g}, 0.12 \mathrm{~mol})$ とメチ ルエチルケトン（23.1 g, $0.32 \mathrm{~mol} ）$ に $2 \mathrm{~mol} / 1$ 水酸 化ナトリウム水溶液（125 ml）を加え，室温下で 24 時間かき混ぜたのち, 反応液をエーテル抽出し た．エーテル留去後，析出した結晶を $n$-ヘキサン から再結晶，無色プリズム状結晶 7 $(13.11 \mathrm{~g}$ ，収率 $68 \%$ ）を得た。 $\mathrm{mp} .38-39^{\circ} \mathrm{C}$ (文献值 $38-39^{\circ} \mathrm{C}$ ).

$5: 7(1.6 \mathrm{~g}, 0.01 \mathrm{~mol})$ をエタノール $15 \mathrm{ml}$ に溶 解， $5 \%$ パラジウム-炭素 $0.1 \mathrm{~g}$ を加え, 常圧水素ガ 又雾囲気下で 3 時間かき混ぜた。触媒をろ過，減圧 下にエタノールを留去，無色油状物 5（1.28 g, 79 \%)を得た。

6 : 5 (1.62 g, $0.01 \mathrm{~mol})$ をエタノール $15 \mathrm{ml}$ に溶 解，承冷かく汼下に水素化ホウ素ナトリウム $(0.45$ $\mathrm{g}, 0.012 \mathrm{~mol})$ を 1 時間，かき混ぜながら加え，そ の後， 2 時間かく汼を続けた。 反応溶液を氷-塩酸 に投入，エーテル抽出（3 回），エーテル層を飽和 炭酸水素ナトリウム水溶液で洗浄, $\mathrm{Na}_{2} \mathrm{SO}_{4}$ で乾燥 した。エーテルを留去，無色油状物 6 $(1.32 \mathrm{~g}$ ，収 率 $80 \%$ ）を得た。

$8: 7(1.6 \mathrm{~g}, 0.01 \mathrm{~mol})$ をメタノール $10 \mathrm{ml}$ に溶 解，水冷下にかき混ぜながら $30 \%$ 過酸化水素水 $(1.4 \mathrm{ml}, 0.012 \mathrm{~mol})$ を加えた。さらにかき混ぜな がら， $2 \mathrm{~mol} / 1$ 水酸化ナトリウム水溶液 $2.5 \mathrm{ml}$ を滴 下したのち，1 時間かき混ぜた。析出した反応物を 吸引ろ過，少量の冷メタノールで洗浄後，デシケー 夕中で乾燥し, 無色板状結晶, 1,2-エポキシ-1-フエ ニル-3-ペンタノン $7 \mathrm{a}(1.3 \mathrm{~g}$ ，収率 74\%）を得た。 mp.39-40 ${ }^{\circ}$. IR $(\mathrm{KBr}) \mathrm{cm}^{-1}: 1720(v-\mathrm{C}=\mathrm{O}) ;{ }^{1} \mathrm{H}-$ NMR $\left(\mathrm{CDCl}_{3}\right) \delta: 1.10(3 \mathrm{H}, \mathrm{t}, J=7.0 \mathrm{~Hz}), 2.50(2 \mathrm{H}$, q, $J=7.0 \mathrm{~Hz}), 3.50(1 \mathrm{H}, \mathrm{d}, J=3.0 \mathrm{~Hz}), 3.96(1 \mathrm{H}, \mathrm{d}$, $J=3.0 \mathrm{~Hz}), 7.35(5 \mathrm{H}, \mathrm{s})$. エポキシ体 $7 \mathrm{a}(1.76 \mathrm{~g}$,
$0.01 \mathrm{~mol}$ ）をエタノール $20 \mathrm{ml}$ に溶解， $5 \%$ パラジ ウム-炭素 $(0.1 \mathrm{~g})$ と 2 滴の濃塩酸を加え, 常圧水 素ガス雾囲気下で 3 時間かき混ぜた。 反応後，触媒 をろ過，減圧下にエタノールを留去，淡黄色油状物 $8(1.21 \mathrm{~g}$ ，収率 $68 \%$ ）を得た。

11 : 7a $(1.76 \mathrm{~g}, 0.01 \mathrm{~mol})$ をメタノール $10 \mathrm{ml}$ に 溶解，氷冷下にかき混ぜながら水素化ホウ素ナトリ ウム $(0.45 \mathrm{~g} ， 0.012 \mathrm{~mol})$ を 1 時間かけて加え，さ らに 2 時間かき混ぜた。反応溶液を水一塩酸に投 入，エーテル抽出（3 回），エーテル層を飽和炭酸 水素ナトリウム水溶液で洗浄, $\mathrm{Na}_{2} \mathrm{SO}_{4}$ で乾燥, エーテル留去, 得られた無色油状物 $(1.6 \mathrm{~g})$ をシ クロヘキサンから再結晶，無色針状結晶 $11 （ 1.58$ $\mathrm{g}$ ，収率 $88 \%$ ）を得た。 mp.65.5-67 $\mathrm{C},[\alpha]_{\mathrm{D}}^{24}-25.2$ $(\mathrm{c}=1.0, \mathrm{EtOH}), \mathrm{GC}$ は，菌糸体培養液から得た 11 と一致した。

12: かく挥棒，塩化カルシウム管付滴下ロート, 及び乾燥窒素ガス注入口を付した $500 \mathrm{ml} 3$ ロフラ スコ中に 1-フェニル-1,3-ブタンジオン $(3.24 \mathrm{~g}$, $0.02 \mathrm{~mol})$ の乾燥テトラヒドロフラン溶液 $(20 \mathrm{ml})$ を入れ，水素化ナトリウム $(0.4 \mathrm{~g}, 60 \%$ パラフィ ン懸濁液）を加えて， $-20^{\circ} \mathrm{C}$ で 1 時間反応させた。 次に $n$-ブチルリチウム $(0.01 \mathrm{~mol}, 6.3 \mathrm{ml}$ ヘキサ ン溶液）を加え， 20 分間反応させた。ついで，液 体ホルムアルデヒド $(0.33 \mathrm{~g} 0.011 \mathrm{~mol}$, 冷却 $n-へ$ キサン溶液中） を加え， $-35^{\circ} \mathrm{C}$ で 2 時間反応させ た．反応後，かき混ぜながら飽和塩化アンモニウム 水溶液 $(100 \mathrm{ml})$ を加え室温に戻した。 反応液にエー テル $50 \mathrm{ml}$ を加え，有機層と水層に分離した．水層 を 2 回エーテル抽出，有機層と合し，飽和食塩水で 洗浄した。 エーテル層を $\mathrm{MgSO}_{4}$ で乾燥，エーテル を留去, 得られた混合物 $(3.32 \mathrm{~g})$ を分離精製する ことなしに, ベンゼン $100 \mathrm{ml}$ に溶解， $p$-トルエン スルホン酸（0.2 g) 又は天然クリノプチロライト $(0.1 \mathrm{~g}$ ，秋田県二ツ井産ゼオライト岩）を加え，加 熱還流して，無色鱗片状結晶 $12(1.96 \mathrm{~g}$ 又は 0.65 $\mathrm{g}$ ，収率 $65 \%$ 又は $21 \%$ ）を得た。 mp.68-69 ${ }^{\circ} \mathrm{C}$ （シ クロヘキサン).

\section{結 果と考察}

\section{1. 培養条件と中性精油成分}

培養条件：タンク培養組成物の経時変化を Fig. 1 に示す。菌糸体量は，残存糖がほとんご消失する 8 
日目に最高值を示した。培養液の $p \mathrm{H}$ は，6から約 4 まで低下，8 日以降からは，タンパク質起源塩基 成分の増加により上昇した。中性精油量は，菌糸体 の増殖と共に増加したが，4 日目以降ほぼ一定值を 示した．また，芳香性フェニルペンタノン誘導体は， 3 日目から出現，7日目に最高値に達した。その 間，精油中のベンズアルデヒド $(\mathbf{3})$, ベンジルアル コール(4)が減少，フェニルペンタノン誘導体量が 増加したことから，フェニルペンタノン誘導体は 3 及び 4 等を前駆物質として生産されることが示唆さ れた。

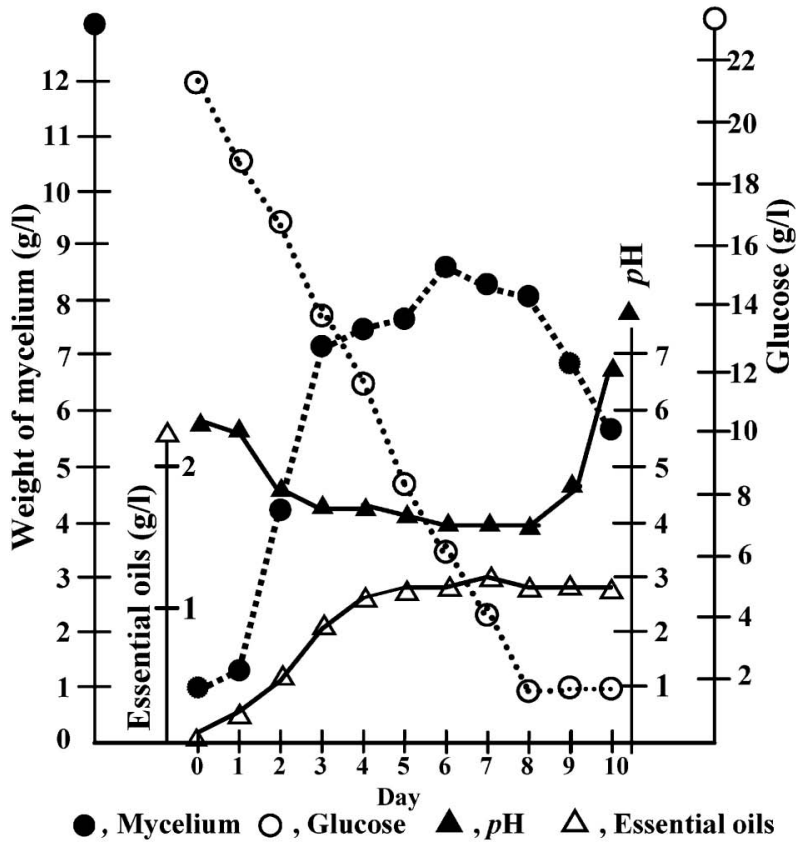

Fig. 1. Cultivation of Mycoleptodonoides aitchisonii Composition of the medium: glucose $20 \mathrm{~g}$, polypeptone $5 \mathrm{~g}$, yeast extracts $2 \mathrm{~g}$, antifoamer $0.005 \mathrm{ml}$, water $1000 \mathrm{ml}$. Submerged culture: $90 \mathrm{l}$ jar fermenter, temperature $25^{\circ} \mathrm{C}$, agitation speed 100 r.p.m., aeration rate 0.8 v.v.m.
中性精油成分：菌糸体をろ過した培養液をエーテ ル抽出して得られた中性精油の GC スペクトルを Fig. 2 に示す。観察 12 成分のピークナンバーを各 化合物 (1) 一(12) とした。

1-4(1：2-ブタノン, 2 : 3-ブテン-2-オン, 3:ベ ンズアルデヒド，4：ベンジルアルコール）は，標 準品と比較，同定した。フコニルペンタノン誘導体 (5-12) は，スペクトル解析と合成（9を除外）に より確認した。すなわち，5 は，1-フェニル-3-ペン 夕ノン，6 は，1-フェニル-3-ペンタノール，7 は， 1-フェニル-1-ペンテン-3-オン， 8 は，1-ヒドロキシ1-フェニル-3-ペンタノンと同定された。9 は, ${ }^{1} \mathrm{H}$ NMR スペクトル解析，及び酸触媒の存在で $\mathbf{1 2}$ へ 異性化することから，5-フェニル-1-ペンテン-3,5-ジ オンのエノール体とした（Scheme 1) . 5) 10 と 11 は，スペクトル解析から，1-フェニル-1,3-ペンタン ジオールの立体異性体と判断した。 $\left.{ }^{6}\right) 12$ は，スぺク トルから 2-フェニル-5,6-ジヒドロ-4H-ピラン-4-オン と推定， Scheme 3 に示す経路により合成確認した (Fig. 3).

2. 12 の生成メカニズムと合成法

9 から 12 への酸異性化：ジヒドロ- $\gamma$-ピロン体

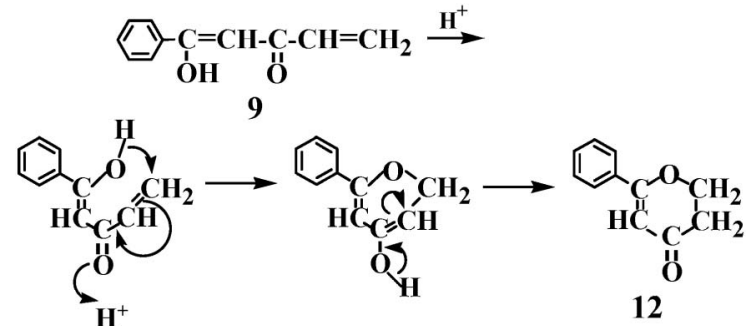

Scheme 1. Isomerization to $\mathbf{1 2}$ from $\mathbf{9}$

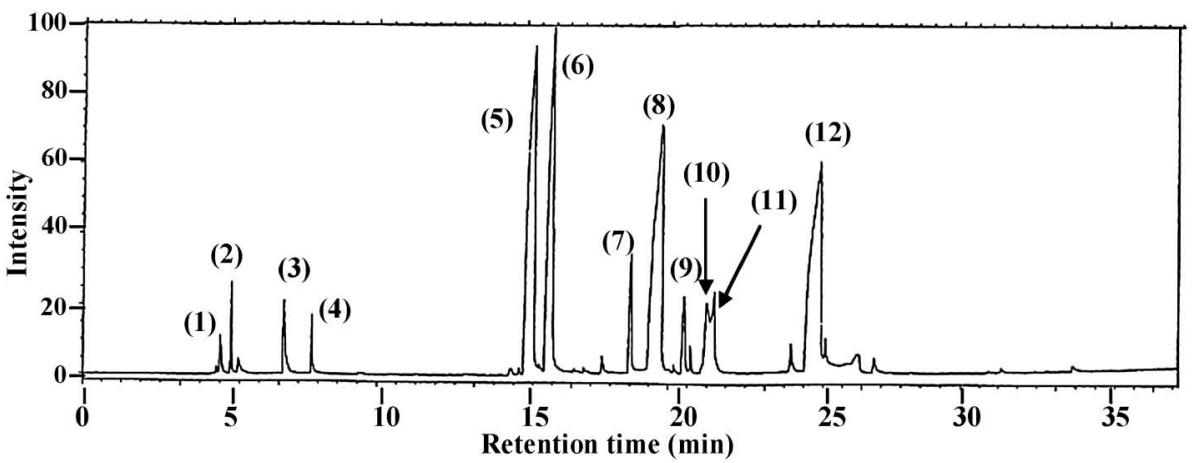

Fig. 2. GC of Neutral Oils for Cultured Mycelium 


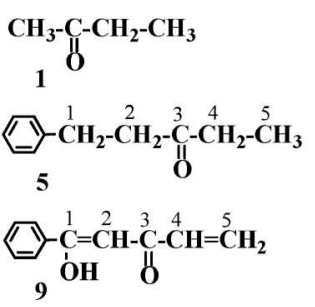

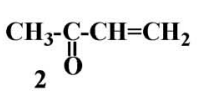

《- $-\mathrm{CH}_{2}-\mathrm{CH}_{2}-\mathrm{CH}-\mathrm{CH}_{2}-\mathrm{CH}_{3}$

$\stackrel{1}{=} \stackrel{1}{\mathrm{C}} \mathrm{H}-\stackrel{2}{\mathrm{C}} \mathrm{H}_{2}-\stackrel{3}{\mathrm{C}} \mathrm{H}-\stackrel{4}{\mathrm{C}} \mathrm{H}_{2}-\stackrel{5}{\mathrm{C}} \mathrm{H}_{3}$ 10 OH

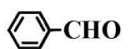

3

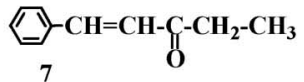

- $-\mathrm{CH}-\mathrm{CH}_{2}-\mathrm{CH}-\mathrm{CH}_{2}-\mathrm{CH}_{3}$ 11 Oे
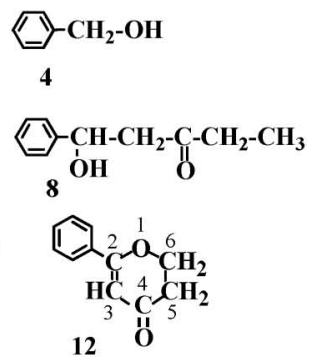

Fig. 3. Structure of 1-12

（12）は，これまで自然生育下では見い出されていな い. 12 は，菌糸体の培養条件下で，9 を前駆物質と して生成したと推定される.9は in vitro で酸を添 加すると，12 異性化することが， ${ }^{1} \mathrm{H}-\mathrm{NMR}$ スペ クトルにより観測された (Scheme 1)。フェニルペ ンタジオン類のケト・エノール互変異性化現象は, ジヒドロ- $\gamma$-ピロン誘導体の合成手法として興味深 い. すなわち，9 を合成して 12 へ異性化する経路 である．12 は，すでに2-フェニル- $\gamma$-ピロンの部分 接触還元, ${ }^{7)}$ 及び 5-イソオキザゾイルエタノールの 接触還元，ついで酸加水分解して得られた $\alpha$-フエ ニル- $\delta$-ヒドロオキシ- $\beta$-ジケトンの閉環により合成 されている. $\left.{ }^{8}, 9\right)$ 前者は，2,4-ジヒドロ体及びテトラ ヒドロ- $\gamma$-ピロンの副生成物を伴うこと，後者は， イソオキサゾール環合成及びその還元開環反応を伴 う多段階反応で，いずれも $40 \%$ 程度の収率である ことから, 本法では容易に合成される $\beta$-ジケトン, 1-フェニル-1,3-ブタンジオンを用いて，ホルムアル デヒドで末端炭素鎖を延長し，閉環させる 2 段階反 応を試みた。

\section{3. $9,10,11$ 及び 12 の構造}

9 の構造 : HPLC で Fr.4 を精製して9 を得た。9 の MS スペクトルは, $\mathbf{M}^{+}(m / z 174), 147\left(\mathbf{M}^{+}-\mathrm{C}_{2}\right.$ $\left.\mathrm{H}_{3}\right), 121\left(\mathrm{M}^{+}-\mathrm{C}_{4} \mathrm{H}_{5}\right)$ 及び 77 のピークを与えた. IR スペクトルは， $3457 \mathrm{~cm}^{-1}$ にエノール型ヒドロ キシル基の吸収, 1715,1677 ，及び $1642 \mathrm{~cm}^{-1}$ に 1,3-ジオンのエノール型カルボニル基の吸収を認め た。また， ${ }^{1} \mathrm{H}-\mathrm{NMR}$ スペクトルは， $\delta 15.62$ にエ ノールヒドロキシル基の広幅な水素原子 1 個分の吸 収が認められた。これらの事実から，9は $\beta$-ジケト ンである 5-フェニル-1-ペンテン-3,5-ジオンのエ ノール型が分子内水素結合を形成しているものと判 断した. ${ }^{5)}$

$\mathbf{1 0}$ と 11 の構造 : HPLC で Fr.4 を精製して 10 と
11 を得た。 MS スペクトルは, MS $m / z: 180\left(\mathrm{M}^{+}\right)$, $162\left(\mathrm{M}^{+}-\mathrm{H}_{2} \mathrm{O}\right), 133\left(\mathrm{M}^{+}-\mathrm{C}_{2} \mathrm{H}_{7} \mathrm{O}\right)$ 及び $107\left(\mathrm{M}^{+}-\mathrm{C}_{4}\right.$ $\left.\mathrm{H}_{9} \mathrm{O}\right)$ と両者の $\mathrm{MS}$ スペクトルは，完全に一致し た。このことから 10 と 11 は相互に立体異性体の関 係にあることを認めた. ${ }^{6}$

12 の構造：12 は9のエノール体が, 培養経過中 に増加する有機酸の存在により, 酸触媒的に異性化 したと推定した.

4. 5, 6, 7, 8, 11 及び 12 の合成法 培養菌糸体 中の芳香性フェニルペンタノン誘導体は，C6-C3C2 骨格を持ち，いずれも C3 位が酸化されてい る。それゆえ， 5, 6, 7, 8, 及び 11 の合成は Scheme 2 に示すように, ベンズアルデヒド $(3)$ とメチルエ チルケトンの縮合で得られる 7 から誘導した。すな わち，7 の二重結合を還元して 5 を合成，5 を水素 化ホウ素ナトリウム還元して 6 を合成，7 の過酸化 水素酸化で得られる 1,2-エポキシ-1-フェニル-3-ペ ンタノン $(\mathbf{7 a})$ を $\mathrm{Pd}$ 水素還元して 8 を得た. 11 は, 7a を水素化ホウ素ナトリウム還元して得た。 また, 12 は 1-フェニル-1,3-ブタンジオン (12a) をテトラヒ ドロフラン中, 乾燥窒素雾囲気下で冷却し, 水素化 ナトリウムと $n$-ブチルリチウムを加えてジアニオ ン中間体を調整し，ホルムアルデヒドを縮合して 12b を得た. 12b を $p$-トルエンスルホン酸, 又は固 体酸である天然クリノプチロライト (CZ: $\mathrm{Si} / \mathrm{Al}$ 比 5 , 八メット酸度関数 $-3.0<H_{0} \leqq+1.5 ）$ とベンゼ ン溶液中, 加熱・還流を行うことで, 環化脱水, 合 成した（Scheme 3).

\section{結論}

非食用部であるブナハリタケ菌糸体を培養するこ とで, 芳香性フェニルペンタノン誘導体 8 種類を単 離した。食味試験で甘味を有する芳香性物質 $\mathbf{1 2}$ は，これまで自然生育下では見られなかった。これ 


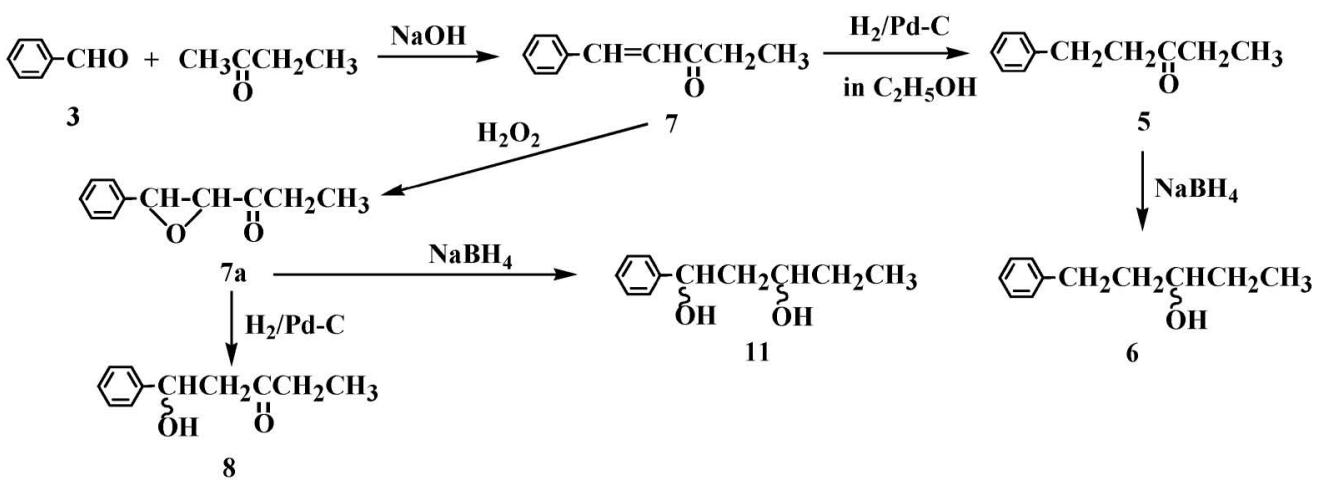

Scheme 2. Syntheses of $\mathbf{5}, \mathbf{6}, \mathbf{7}, \mathbf{8}$, and $\mathbf{1 1}$

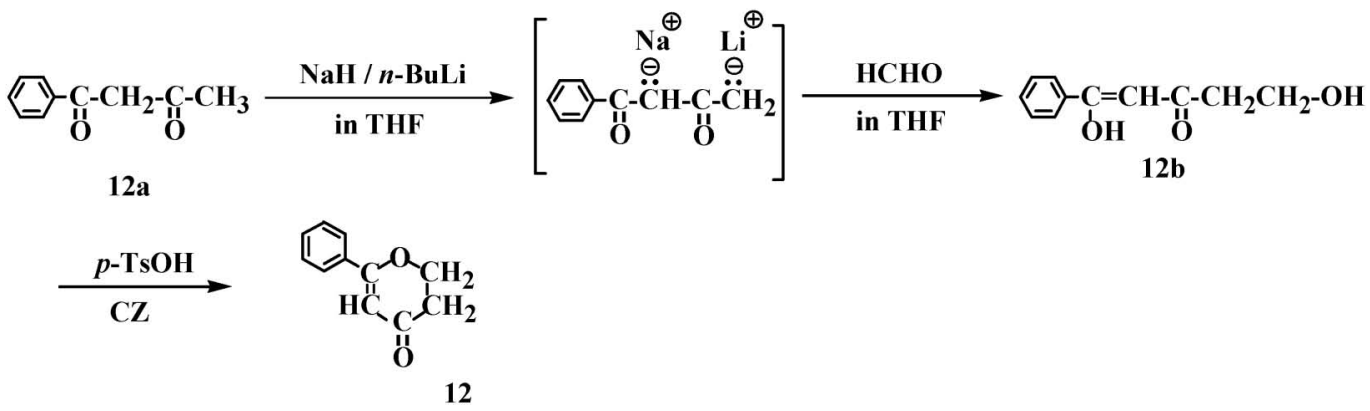

Scheme 3. Synthesis of $\mathbf{1 2}$

らの化合物は, 芳香剂, 医薬資源としての利用が期 待される.

謝辞ブナハリタケ菌糸体の培養は, 秋田十條 化成秼井上俊三博士，及び佐藤博子氏の支援の下で 行った。本報告で述べた培養法, 並びに化合物 $\mathbf{1 2}$

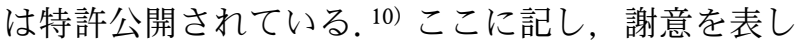
ます。 また施光度測定に便宜を頂いた秋田県農林水 産技術センター総合食品研究所の堀一之博士に御 礼申し上げます。

\section{REFERENCES}

1) Okuyama S., Yokogoshi H., Kawagishi H., "Biological Activity and Function of Mushrooms, Supervisor": CMC Shuppan, Chapter 13, 2005, pp. 196-207.

2) Sawazaki E., Okuyama S., Yokogoshi H., $A$ roma Res., 5 (3), 254-258 (2004).

3) Satoh K., Sato H., Inoue S., Abe N., The Ab- stract at the 34th Annual Meeting of TEAC, 1990, p. 11.

4) Satoh K., Sato H., Inoue S., Abe N., The Abstract at the Annual Meeting of the Chemical Society of Japan for Tohoku District, 1991, p. 114.

5) Satoh K., Sato H., Inoue S., Abe N., The Abstract at the Annual Meeting of the Chemical Society of Japan for Tohoku District, 1997, p. 162.

6) Utimoto U., Uchida K., Yamada M., Nozaki H., Tetrahedron, 33, 1945-1949 (1977) .

7) Cornbert R., Real M., Thomas P., Bull. Soc. Chim. Fr., 1954, 534-536.

8) Casnati G., Quilico A., Ricca A., Vita-Finzi P., Gazz. Chim. Ital., 96 (8-9), 1073-1083 (1966).

9) Casnati G., Quilico A., Ricca A., Vita-Finzi P., Tetrahedron Lett., 1966 (2), 233-238.

10) Sato H., Inoue S., Yokota K., Tokkyokouho 4-45793 (1992). 